\title{
SASKATCHEWAN BIRD BANDERS* F. J. HARTLEY FREDEEN OF MACRORIE
}

by C. Stuart Houston, 863 University Drive, Saskatoon

Hartley Fredeen obtained a banding permit in 1938 and banded on his parents' farm near Macrorie, Saskatchewan, until the spring of 1944. Altogether, with the help of other members of his family, he banded about 1500 individuals of 49 species. Some of the more interesting species banded included the Willet, Upland Plover, Sharp-tailed Grouse, Redshafted Flicker, Sprague's Pipit, and Sharp-tailed Sparrow. The smaller birds were caught chiefly in funnel traps and drop traps whereas crows and hawks were banded as nestlings.

From this banding, there were at least 27 recoveries. Mallards travelled to Saskatoon, to Kathryn, Alberta, to Glenora, Manitoba, and to Sugar City, Colorado. An American Widgeon was caught uninjured by a dog that same fall near Salt Lake City, Utah and released uniharmed. A Common Grackle was found dead over a year later near Anerly, Saskatchewan, while others were shot in Arkansas and Mississippi. A Loggerhead Shrike banded August 21, 1938 was found dead near Paul's Valley, Oklahoma on December 20, 1938. A nestling Barn Swallow was found dead the following June near Courval, Saskatchewan and another was caught by a cat near Cadillac, Saskatchewan before June 1, two years later; they may have been nesting 90 and 135 miles, respectively, south of their hatching site. Another Barn Swallow was found dead in fall migration near Volga, South Dakota. A Western Meadowlark was shot near Arcadia, Oklahoma, and two Redwinged Blackbirds were found near Ashby and Dumont, Minnesota.

A Brewer's Blackbird was found dead two years later near Tramping Lake, Saskatchewan and a Savannah Sparrow was caught by a cat west of Lucky Lake, Saskatchewan, the same fall. Crows were shot in South Dakota, Nebraska and Oklahoma.
The recoveries of greatest interest are those of two Marsh Hawks listed in the March 1968 Blue Jay, and the three Swainson's Hawks listed in this issue. The Swainson's Hawk recovery from Rosario, Argentina, is the farthest south recovery of any bird of any species ever banded in Saskatchewan.

Hartley's early interests led him to a career in biology. His summers while a University student were spent in fisheries research in Saskatchewan and the alpine lakes of Alberta. In 1942 when the University of Saskatchewan made a survey of the resources of the Big River area of Saskatchewan, Hartley was delegated to prepare the report on the birds.

$\mathrm{He}$ is now an entomologist at the Canada Agriculture Research Station on the Saskatoon campus and specializes in studies of pest species of insects that inhabit rivers. He has just completed a project on the St. Lawrence River in Quebec and is now involved with a project on the Athabasca River. He has been a member of the Saskatchewan Natural History Society since its inception.

*This is No. 9 in a series of biographies of Saskatchewan Bird Banders by C. Stuart Houston.

\section{INFORMATION WANTED}

Anyone finding a Ferruginous Hawk nest anywhere in the province or a Swainson's Hawk nest within 150 miles of Saskatoon or 50 miles of Regina or Yorkton, please write Dr. Stuart Houston at 863 University Drive, Saskatoon.

To date, we know virtually nothing of the movements of the Ferruginous Hawk. 